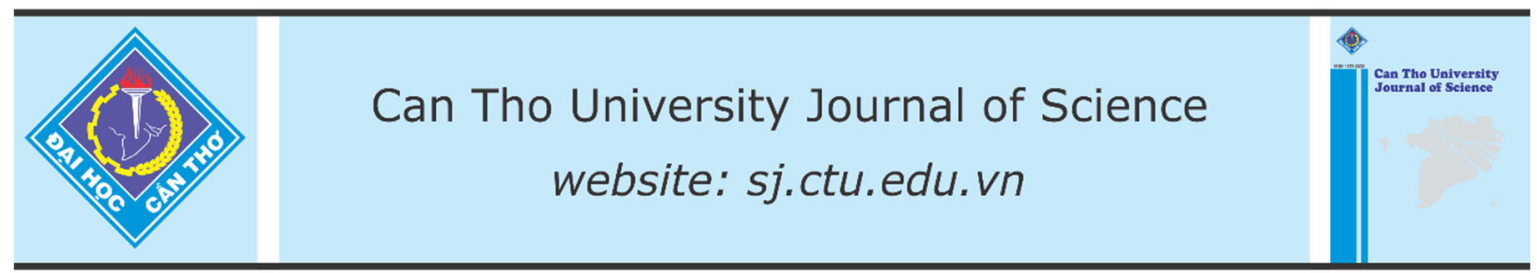

DOI: $10.22144 /$ ctu.jen.2019.007

\title{
A review of factors influencing learners' gain of English proficiency
}

\author{
Phuong Hoang Yen*, Tran Mai Hien and Vo Phuong Quyen \\ School of Foreign Languages, Can Tho University, Vietnam \\ *Correspondence: Phuong Hoang Yen (email: phyen@ctu.edu.vn)
}

\section{Article info.}

Received 10 Aug 2018

Revised 08 Nov 2018

Accepted 29 Mar 2019

\section{Keywords}

EFL learners, English proficiency, influencing factors, progress

\begin{abstract}
Different factors are involved in the process of learners learning English as a second or foreign language. Some contribute to enhancing their English proficiency, others mitigate and or even delay the process of learners' mastering the language. Throughout literature, many studies focus on one or several factors that have an impact on learners' gain of English language proficiency. Few studies have been conducted to explore groups of factors together. The current paper reviews different studies on the issue to provide the whole picture of what may play a role in influencing Englishas-a-foreign-language learners' improvement of English proficiency. Three groups of factors are discussed including student-related factors, teacher-related factors and context-related factors. The paper also implies what different stakeholders can do to maximize and optimize learners' gain and progress in English language learning.
\end{abstract}

Cited as: Yen, P.H., Hien, T.M. and Quyen, V.P., 2019. A review of factors influencing learners' gain of English proficiency. Can Tho University Journal of Science. 11(1): 49-59.

\section{INTRODUCTION}

English has become an international language and been used popularly in many areas of life all over the world. Therefore, people of different ages and nationalities have been learning English for communicating with others, learning abroad, looking for jobs, entertaining, and so on. However, while some people can acquire English easily, others have been struggling to learn the so-called lingua-franca. Across literature on English language teaching and learning, researchers conducted different studies to explore individual factors that have an impact on learners' English proficiency levels. However, almost no studies have been implemented to synthesize all such factors together. Meanwhile, such a review of influencing factors will raise the awareness of learners, teachers and researchers of the English language as well as help them optimize the favorable factors and mitigate the negative ones. The current review is such an attempt.

In order to conduct the review, different scientific resources have been consulted, including Google Scholar, Science Direct, Web of Science, SCOPUS, and ERIC. In addition, specific journals focusing on factors influencing learners' gain of English proficiency were checked upon. The articles being reviewed have been published in the past 30 years.

As for keywords, a combination of different phrases focusing on factors influencing learners' gain of English language proficiency were used. These included "factors influencing English language proficiency" or "impact on English language proficiency" and "second language (L2) learning" or "Engish as a foreign language (EFL) setting" or "EFL classroom" or "English language teaching".

A snow-balling approach was also employed, i.e. once a relevant article was found, the researchers 
consulted the referenced list and the journal in which the article was published to search for more relevant article.

Three clusters of learner-related factors, teacherrelated factors and context-related factors have been discovered and will be described in details in the coming parts of the paper. The review sheds some light on the impact of different factors that may boost learners' English acquisition or prevent them from making progress in English learning. Thus, it will be a good source of references for related stakeholders whenever they want to enhance English language teaching and learning in their own context.

\section{LEANER-RELATED FACTORS}

The level of learners' English language proficiency is significantly influenced by various factors related to learners themselves. These factors include learners' learning autonomy, learners' motivation and attitudes to English language learning, and learners' learning strategies. The following part will detail major issues related to such three factors.

\subsection{Learners' learning autonomy}

Learners' learning autonomy can be considered as one of the crucial factors affecting their level of proficiency in English language. As Hedge (2000, p.410) explained, autonomy is "the ability of the learner to take responsibility for his or her own learning, and to plan, organize, monitor the learning process independently of the teacher". Sharing the same concern, Little (2007) emphasizes that autonomous learners are aware of their strengths and weaknesses, so they are motivated to be responsible for their own learning. The author further implies that the more the level of learner autonomy is enhanced, the more the growth of learners' target language proficiency is achieved. In other words, learners' learning autonomy is implied as an inevitably existing contributor to the level of English learners' proficiency.

Following the above concern, several studies have proved a close-knit relationship between learners' learning autonomy and their level of English language proficiency. In particular, Dafei (2007) explores the relationship between autonomy and English language proficiency revealed by 129 nonEnglish majored students in a teacher college in China by means of a questionnaire and an interview. The result showed a significant and positive differences between two variables. This means that learners' level of proficiency showed differences resulted in the significant differences in their autonomy. Additionally, Nguyen (2008) studied the relationship between learner autonomy and Vietnamese English-majored students' English language proficiency. She studied 77 English majors from a university in Vietnam and used the questionnaires for this purpose. Based on the results, Nguyen has found positive and significant correlations between most aspects of learner autonomy and English as foreign language (EFL) proficiency measures. Explained more specifically, particular aspects of learners' learning autonomy have been clarified such as having an intrinsic interest in English, trying hard to use English out of class, and being able to plan, monitor, and evaluate their own learning. These aspects are concluded as main contributors to learners' success in English language achievement. In the context of Iran, Hashemian and Soureshjani (2011) investigates the interrelationship of autonomy, motivation, and English language performance. The study was conducted with 60 Persian learners. Two questionnaires, one for autonomy and another for motivation, were deployed to gather the required data which were was then analyzed through correlation and regression. The bivariate correlation reported a positive significant correlation between learner autonomy and English language performance. Similar implications have also been found in the study by Mohamadpour (2013) to explore the autonomy level of 30 senior high school students in Tehran by means of a questionnaire and interview and their English proficiency using PET (Preliminary English Test). The results showed that learners' autonomy and the English proficiency of the participants are positively correlated. Hence, the author concluded that the more autonomous the English language learners are, the more proficient they would be. Another study by Myartawan et al. (2013) is aimed to determine the correlation between learner autonomy and English proficiency of 120 student participants selected by using a proportionate sampling technique from a population of 171 first semester students of the English Education Department, Ganesha University of Education (Undiksha) in Bali, Indonesia. The data were obtained from documents and questionnaires. In this study, the multiple linear regression analysis revealed that learner autonomy and English proficiency as defined in the study had a significant, strong, positive relationship. It is clearly stated that learners' learning autonomy and their language proficiency are closely interrelated.

\subsection{Learners' motivation and attitude to English language learning}

Another factor contributing to the level of proficiency in English among learners is related to 
their motivation and attitudes to English language learning (Spolsky, 1989; Gardner and Lambert, 1972; Littlewood, 1984; Brown, 2007; Holmes, 2017). As Gardner and Lambert (1972) clarify, learners with high level of motivation grounded in positive attitudes towards the second language will be successful in second language learning while learners with negative attitudes are related to learners' anxiousness, making them unsuccessful in second language acquisition. Based on Brown's (2007, p.114) definition of motivation which is "an inner drive impulse, emotion or desire that moves one to a particular action and motivation is a taskoriented", Daskalovska et al. (2012) further add that a motivated language learner desires to achieve learning goals and willingly spends time and effort reaching that goal, so learners' motivation to learn the language can be considered as one of the most important factors enhancing their language proficiency.

Several studies have investigated learners' learning motivation and attitudes and the language proficiency, and their implications showed the tangible relationship between learners' motivation and attitude, and their English language proficiency. For example, a study in Turkey by İnal et al. (2003) was conducted with 421 learners from different school contexts. The findings showed that learners' attitudes towards English language received a higher positive correlation with their learning achievement compared to other variables such as high school type, second language, medium of instruction, parents' education, and living abroad. In another context, Eun-Hee and Hee Jeong (2011) investigate 92 first-year Korean university students who took a mandatory English course by a means of a questionnaire on their motivation to learn English and answered short essay questions related to their preferences in English courses. Data analysis indicated that students' interest was the only factor contributing to the participants' scores improvement. A study by Al-Mahrooqil (2012) employing a qualitative questionnaire with focus groups and personal reports from 100 tertiary education students revealed that lacking motivation in English learning can be considered as one major factor leading students' low English language proficiency.

With the focus on clarifying the relationships of both motivation and attitude, and English language proficiency, Liu (2007) investigates Chinese university students' attitudes and motivation to learn English and the correlations of both variables with the students' English proficiency. The study conducted with 202 Chinese third-year English non- majored students and adapted the motivation survey by Gardner (1985) and an English proficiency test. The finding from the correlation analysis revealed that the students with more positive attitudes towards learning English tended to score higher in the proficiency test, and those who were more instrumentally motivated tended to perform better in the test. Liu emphasizes these factors contributed to the result of students' higher English proficiency. Following the same research instrument- a questionnaire survey on attitudes and motivation adapted Gardner's (1985) Attitude and Motivation Test Battery, Ming et al. (2011) conducted a study with 143 Chinese, Malay and Iban students from both Science and Art classes in East Malaysia studying English as a second language. The data were analysed using the descriptive correlation coefficient and ANOVA inferential tools. The study revealed that the better students had more positive attitudes and showed greater initiatives towards learning English than the weak students. However, students' extrinsic motivation was perceived as a more influential factor for students to learn English than their intrinsic motivation. Sharing the same vein, a recent study by Phon (2017) investigate the relationship between students' English proficiency levels with three variables, namely socioeconomic status, learning motivations and attitudes, and learning opportunities. The study employed a set of questionnaires adapted from the general theory of language learning of Spolsky's (1989) model with 15 English-majored students at a rural public university in Cambodia. The data were then analyzed by Spearman's correlation and the findings indicated that learners' motivation and learning attitude had a strong correlation with learners' English language proficiency level compared to other variables. As consequence, learners' motivation and attitudes play a vital role to improve learners' proficiency in English language, or learners of second language must have both motivation and attitude to achieve their success in language proficiency.

\subsection{Learners' learning strategies}

Learners' learning strategies have long been discussed as another integral contributor to their language proficiency (Rubin, 1975; Chastain, 1988; Vann and Abraham, 1990; Chamot and O'Malley, 1994; Cummins and Swain, 2014). As Cook (2016) claimed, good and proficient second language users might acquire such language through different strategies. Explained by another way, the more proficient learners use a greater variety of language strategies and perform such strategies more effectively than their less proficient peers or less 
effective learners tend to show their lack or limitation of learning strategies knowledge (Oxford, 1990), To verify language strategies, Oxford (1990) constructs the instrument of Strategy Inventory for Language Learning (SILL) with six categories of learning strategies, namely memory strategies, cognitive strategies, compensation strategies, metacognitive strategies, affective strategies, and social strategies.

Followed by the SILL survey, various studies in different contexts of English as a second language have been undertaken to disclose a strong correlation between strategy use and language proficiency. A research in Korea conducted by Park (1995) used the SILL to measure learning strategy preferences of 332 university students studying English as a foreign language and a practice version of the Test of English as a Foreign Language (TOEFL) later used to determine English proficiency level. The results showed all of the identified SILL categories were significantly correlated with students' English proficiency, but cognitive and social strategies were more predictive of TOEFL scores than other strategies. Similarly, Nisbet et al. (2005) explored the relationship between the language learning strategy preference and English language proficiency among 168 third-year English-majored students at Henan University in Kaifeng, China, using the the same instruments (the SILL and the TOEFL). The finding revealed significant variation in proficiency in relation to eleven out of a possible fifty strategies. More precisely, the results significantly showed that a multiple regression analysis indicated that a combination of two variables (metacognitive strategies and affective strategies) was also significantly correlated with English proficiency. Additionally, Gharbavi and Mousavi (2012) find out whether there is any relationship between the employment of different strategies and learners' levels of language proficiency. The participants were 90 university students majoring in teaching English as a foreign language (TEFL) at Payame-Noor Universities of Khoramshar and Abadan in Iran. By comparing the variances of the obtained scores of the TOEFL and the scores of the SILL, the results showed the correlation coefficient of 0.91 , which means there is a relationship between the learner's proficiency level and the adoption of the strategies by the language learners. In particular, the findings indicated that advanced language learners achieve stability in using strategies which is not found in the lower level language learners. In other words, the authors concluded that the more proficient the learners are, the greater the number of strategies they use. Despite using the same research instruments (the SILL and the TOEFL), a study by Madhumathi et al. (2012) conducted with 60 English as a second language (ESL) students at a private university in South India with a slightly different focus on the low proficiency students' strategy use. Particularly, the finding reported that there was a linear relationship between low language proficiency students and their language learning strategy use. Among the six categories of language learning strategies, compensation, cognitive and metacognitive significantly correlated with TOEFL scores of the low proficiency students.

These studies clearly reveal a significant aspect of the tangible relationship between language learning strategies and English language proficiency. As a result, language learning strategies can be an inevitably important learner-related factor contributing to their language proficiency achievement.

\section{TEACHER-RELATED FACTORS}

Language learning process not only is affected by internal factors, which learners bring with them to the particular situation, but also relies on a number of different external factors (Madrid, 1995; Shoebottom, 2016). The key factor that has a great impact on learners' learning progress is teachers (Geringer, 2003). In English language teaching, the influencing factors related to the teacher include the quality of teachers, teachers' pedagogical knowledge and skills, teacher' teaching approaches, assessment and giving feedback.

Teacher quality is considered to be the most important teacher-related factor that influence learners' learning outcomes (Punthumasen, 2007). The issue of teacher quality has been approached differently by various researchers and educators in the field. Some of them remark that command of the subject area, appropriate teaching methods, and different teaching-related skills represent teaching characteristics. Others focus on personal characteristics, their compassion, humor, innovation, and honesty (Flowerdew et al., 2007). Although in general, good teachers share similar qualities regardless of their disciplines, effective EFL teachers are vitally different from other teachers because of the nature of English as a teaching subject (Al-Mahrooqi et al., 2015).

\subsection{Teacher's language competence}

Researchers on English language teaching have long been agreed on the importance of teacher's command of English as a fundamental factor influencing learner's language development. Mitchell et al. (1988) views language proficiency as the decisive element for the teacher's ability to engage in effective language teaching. With similar viewpoint, $\mathrm{Cul}-$ len (2002, p.220) asserts that the teacher's limited 
command of English influencing a number of aspects of teaching: "A teacher with a poor or hesitant command of spoken English will have difficulty with essential classroom teaching procedures such as giving instructions, asking questions on text, explaining the meaning of a word or replying to a learner's question or remark ... A teacher without the requisite language skills will crucially lack authority and self-confidence in the classroom, and this will affect all aspects of his or her performance".

Mahmoud and Thabet (2013) consider mastery of English including sound pronunciation, and more actively involving students in classroom activities more important characteristics among EFL teachers. According to_Brosh (1996), effective EFL teachers are those who focus on comprehension, are in command of the language, prepare interesting lessons, help students to be independent, and deal with students fairly. Language proficiency is, therefore, key to a teacher's ability to effectively perform their role as language teachers (Richard, 2017), besides pedagogical skills and attitudes.

The fact that teacher's language competence deeply influence learning environment, and learner's language outcomes is presented in a number of studies. Nel and Müller (2010) researched practicing teachers who enrolled for the Academic English: Inclusive Education course in 2008 and 2009. The results reveals that the teacher's poor command of English negatively affects the learners' English language acquisition and academic progress. Young et al. (2014) reveal that many teachers 'recognize that their command of English is not fully adequate for their professional work, both for classroom teaching of English in English and for potential engagement with the global ELT community'. The results of the study carried out by Costa and Coleman (2013) show that a number of teachers in Italy had to participate in a compelled English-taught Programs, which is surprisingly similar to those of Wongsothorn et al. (2002).

Obviously, there is a discrepancy between the expectation and reality of EFL teacher's level of language proficiency, which directly affect the quality of teaching and learning. Elder (2001) and Richards et al. (2013) share conclusion that the 'limitations in language teachers' command of their teaching language is an issue that has been a concern in language teacher education for both teachers of English as well as those who teach other second or foreign languages.' Similarly, Aguilar and Rodríguez (2012) assert that a teacher's insufficient level of English is considered one of the major concerns in today's language teaching.

\subsection{Pedagogical knowledge and skills}

According to Freeman (2016), in language teaching, language is both the content of teaching and the means of teaching that content. Therefore, ability to teach English through English requires a teacher to consider various issues. Knowing about and how to use a language is insufficient to support and enhance language learning. A teacher who is mastering content knowledge, but lacks the ability to present her knowledge in a comprehensible way to her learners is a teacher who lacks pedagogical knowledge and ability (Andrews, 2001).

The importance of pedagogical knowledge and teaching ability is reinforced by a number of researchers. Richard (2017) discusses that pedagogical knowledge and skills enable an English teacher to know the important aspects of language needed for different levels of language proficiency, how to organize a syllabus as well as selecting appropriate teaching strategies and techniques. Skills are also one of the three areas that Borg (2006) considers as the basis that characteristics of EFL teachers are built on. Knowing how to teach and behave appropriately in the target language enables teachers to effectively adapt their teaching 'to the diverse interests and abilities of learners' (Shulman, 1987, p. 8) to best enhance their language proficiency.

One of the most important skills for EFL teachers to master is the discourse skill, which is presented in the ability to maintain communication in a specific genre for classroom instruction, i.e. to teach English through English. The work of Freeman (2016) and others suggest that ability to use English in a way that supports the learning of English is something that not only non-native English teachers but also teachers whose native language is English have to master. Richard (2017) insists on the fact that using English effectively and appropriately in the language classroom settings to facilitate learning requires native-speakers of English to put a lot of effort and energy. In line with Borg (2006) and Mahmoud and Thabet (2013), the results of the study by Al-Mahrooqi et al. (2015) on secondary and high school students highlight the important impact of classroom instruction on learning. Students maintain that their EFL teachers' having a good command of English as well as clear speaking and writing are most important. Young et al. (2014) confirms 'For students at the elementary and secondary school levels, access to teachers who have the necessary professional knowledge and functional English language skills to teach English effectively is critical'. 
The teacher is believed to play the key role to motivate language learners. Strengthening this belief, Dörnyei (2007) and Wong (2010) explain the role of teachers in creating the student's necessary motivating character within the educational context through conscious intervention; therefore, the teacher plays a significant role in creating and fostering the teaching and learning atmosphere. Similarly, the study of Thanasoulas (2002) emphasizes the importance of teachers' skill in motivating students to learn, which subsequently influences the success of foreign language learning. Some motivational strategies include increasing learners' self-confidence in using the target language, creating learners' autonomy such as allowing them to generate to some extent their ideas on necessary classroom activities, and encouraging positive self-evaluation such as providing motivational feedback regarding their language skills. Motivation, consequently, is the variable that teachers can implement and promote in the classroom to enhance language learning (Winke, 2005).

In the subject content classrooms, in which English is a medium of instruction, there is teachers' failure to help learners practice language skills. Uys et al. (2007) pointed out five main reasons. Three among them are the teacher's (1) lack of the knowledge and skills for teaching the four language skills as well as insights into teaching strategies to promote effective instructions, (2) ignorance of the importance of applying pedagogical skills, and (3) lack of skills for teaching through the medium of English. Similarly, the point of view shared by $\mathrm{Li}$ (2009) and Shoebottom (2011) confirms that EFL language learners will experience a faster speed of English development if their teachers both use English in teaching academic subjects and are responsible for students' overall English language development.

\subsection{Teaching approaches and methods}

In EFL context, communicative language teaching (CLT) approach has been given larger attention and wider implementation. Richards (2006) comments that CLT is the methodology of choice by the majority of language teachers today and has greatly influenced approaches to language teaching as well as language teaching practice worldwide. According to Jacobs and Farrell (2003), the shift towards CLT marks a paradigm shift in thinking about teachers, learning, and teaching. The changes include focusing greatly on learner-centered instruction, processorientation instruction, individual differences, and life-long learning. Jacobs and Farrell (2003) also indicate the major changes in approach to language teaching, two important of which are alternative assessment and teachers as co-learners.
In an attempt to find out the influence of teaching approaches on learners' writing skills, Kim (2013) maintains that teaching approach is the most important factor influencing learners' attitudes toward learning, i.e. teaching approaches impact greatly on the level of effort learners make to learn to write in English.

While there is still not a universally accepted methodology worldwide, the shifts in current CLT have led to development of different teaching approaches such as task-based instruction (Richards, 2006). The study by Albino (2017) sought out the effect of task-based language teaching (TBLT) as conceived by Long and Crookes (1992) and Ellis (2009), which focuses on meaning and linguistic form on EFL learners in Cazenga. Findings indicated a progress in speaking ability in terms of fluency, selfconfidence development, vocabulary expansion, and stronger motivation in using target language. Long and Crookes (1992) and Ellis (2009) suggest the incorporation of task components to language syllabus in order for the students to learn and use English as the way English is used outside the classroom.

One remarkable viewpoint, as commented in Hassan and Selamat (2002) and Solak and Bayar (2015) is that classroom activities and materials need to balance among the four language skills. Birjandi et al. (2006) observes a similar EFL setting in which most of the Iranian learners learn English through reading which is a priority skill among the four skills. The reason is that teachers place unequal importance on four language skills, and speaking skill is mostly neglected. The neglect of oral communication practice in the classroom impede language proficiency and the development of other aspects of language skills (Zhang et al., 1995).

\subsection{Assessment and feedback giving}

Teachers' assessment beliefs shape classroom practices and therefore influence learners' motivation and learning strategies. Akbari (2015) discusses the accountability purposes of assessment, which enable teachers to build classroom practices based on the demand of exams, influence the learner's language proficiency negatively. Unfortunately, a large number of teachers prepare their students to cope with examinations and teach English for testing purposes only (Khaniya, 1990; Alderson and Wall, 1993; Hosseini, 2007).

Although teachers are encouraged to use formative assessment during class, their focus on learner's performance in exams instead of meaningful language performance prevent them from employing this type 
of assessment. Green (2014) comments, 'Alternative assessment forms are often more engaging and may be more useful and more enlightening about learning processes'; however, a large number of teachers still focus on summative assessment because they do not have enough knowledge and skill to implement (Akbari, 2015). Therefore, forms of assessment might be one of the reasons behind the failures of learners to acquire the expected level of proficiency in English.

Giving feedback is another contributing factor in developing students' English proficiency (Ueasiriwatthanachai, 2013). Meaningful and positive feedback is crucial to learners' language learning process because it helped them achieve English accuracy and realize their own strengths and weaknesses (Pica et al.,1996; Mackey, 1999; Gass and Mackey, 2007). Meaningful and positive feedback could leads to a reduction in anxiety, resulting in more language communications, and positive language learning outcomes.

\section{CONTEXT-RELATED FACTORS}

A number of researchers (e.g. Firth and Wagner, 1997; Collentine and Freed, 2004; Tarone, 2007) have remarked that in order to help learners be competent in a foreign language, it is necessary to take into consideration the issue of the context-related factors since they serve as some of the major factors promoting successful language learning. The context of learning is of great importance as it is seen to be directly related to students' learning outcomes. Four influential contextual factors in foreign language learning are students' socio-economic background, input-output opportunities, teaching practices and learning activities, and learning environment.

\subsection{Socio-economic backgrounds}

There is a strong link between students' social background factors and their educational access and outcomes (Crawford, 2014). Students' social background includes their racial origin, family income, family structure, and the level of parental education. Ross and $\mathrm{Wu}$ (1995) made a generalization that once the social status and their family's income are increasing, students tend to progress better in their academic performance. A study by Olaitan (2012) revealed the kind of schools students are attending depends largely on their socio-economic background. Thus, what and how they are educated in such schools depend on their socio-economic status (Olaitan, 2012).
In the study by Khattak et al. (2011), the poor socioeconomic background is one of the factors that creates challenges that learners face in learning English in Pakistan. Similarly, Tanveer (2007) figures out that the differences in social status of the students are the factors that lead to their weakness of language learning in the United Kingdom.

\subsection{Input-output opportunities}

Language prominence is related to the number and nature of linguistic input and output opportunities provided for language learners in the curricular and extra-curricular learning contexts (Housen et al., 2011). Regarding the language input, Housen et al. (2011) claim that "the more prominent the second language (L2) is in the learning context, and the less prominent the target language (L1), the more L2 acquisition will be promoted" (p. 88). In the same vein, Baker and Hengeveld (2012) also assert that contact with the target language plays an essential role in foreign language learning since "the time and opportunities you have for using the target language will strongly influence the speed of second language acquisition" (p. 68). In details, linguistic input is thought of as an essential component for language learning in that it helps to provide the learners with information about what is possible or grammatical in the language (Krashen, 1985; Ellis, 2003; Gass and Mackey, 2007). More generally, second language students with more access academic resources (e.g. books, teachers, educational websites) seem to be more successful that those without (Mitchell and Myles, 2001).

Besides being giving maximized opportunities for target language input, learners also need to be given the opportunities to produce meaningful output. In fact, these output-producing opportunities help them to notice a gap in their linguistic knowledge of the second language (Hedge, 2000; Swain, 1985, as cited in Wang and Castro, 2010). In order to do so, learners should be provided with opportunities to engage in meaningful interaction, which in turn, allows them to receive feedback which is said to play a key role in facilitating foreign language learning and development (Mackey, 1999; Pica et al., 1996). Normazidah et al. (2012) and Trawiński (2005) presented that the two factors that impact the EFL learners' poor performance in English language learning are a lack of support to use English in the home environment and the community and learners' insufficiency or lack of exposure to the language as there is a limited opportunity to use English outside the classrooms. Therefore, opportunities for producing meaningful output are not less important than those for being provided with foreign language input. 


\subsection{Learning environment}

Learning environment can be defined as settings, both inside and outside the classroom, in which second or foreign language learning can take place. The learning environment is believed to influence students' language learning process and eventually affect their learning outcomes with regard to language proficiency (Ellis, 2008, cited in Housen et al., 2011). Nikitina (2011) and Wang (2009) pointed out that to facilitate language learning development, foreign language learning environment must be created in such a way that it leads to authentic learning. One of the ways to create authentic learning is, as Nikitina (2011) suggested, using authentic and communicative learning activities because they create real-life experiences in the foreign language classroom and stimulate the authentic use of the target language.

Another measure to create effective learning environment is related to the emotional aspect of learning environment. Several researchers (e.g. Thanasoulas, 2002; Dörnyei, 2007; Azarnoosh and Tabatabaee, 2008) claimed that successful foreign language learning cannot be taken place if and many students consider the learning environment as no the learning context does not provide students with learning motivationt just an intellectual space, but also as an emotional one.

An important environment for students' learning is the classroom. Researchers such as Bahous et al. (2011) and Dörnyei (2007) claim that a positive and motivating classroom climate is considered a factor contributing to the attainment of a successful language learning outcome. In the same vein, Michigan Department of Education (2011) states that "In a supportive and responsive environment, students feel more confident and capable of accessing the language and content" (p. 1). Indeed, a comfortable, motivating, and tension-free classroom environment can help creating a low affective filter as in "Affective Filter Hypothesis", which allows students to learn the language faster and better (Krashen, 1982, cited in VanPatten and Williams, 2007). On the other hand, a tense classroom climate can undermine learning and demotivate learners (Thanasoulas, 2002). In the same vein, Souriyavongsa's (2013) study reveals that unsupportive classroom learning environment is one of the major causes of Laos students' low English performance. Unsupportive classroom climate made them be afraid and feel ashamed when making English mistakes, which results in their lack of confidence in their spoken English.
The role of learning environment in teaching and learning a foreign language reveals that creating the environment that supports language learning definitely results in students having much better language performance.

\section{CONCLUSION AND RECOMMENDATIONS}

Three groups of factors contribute to students' process of learning English as a second or foreign language. The first group of student-related factors includes students' learning autonomy, motivation, attitude, and strategies. The second group of teacher-related factors consists of teachers' quality, pedagogical knowledge and skills, teaching approaches and methods, and assessment and feedback giving. The last group of context-related factors includes socio-economic background, inputoutput opportunities, and learning environment. The diversity of factors implies that different stakeholders can intervene to help students improve their English proficiency efficiently. First and foremost, students themselves must be aware that they are the main agent in their own learning process. If they want to gain better English proficiency, they have to be autonomous in their learning, find ways to increase their own learning motivation and positive attitude toward the process, as well as accumulate different learning strategies.

Regarding EFL teachers, they should continue learning and improving in their teaching career to be able to provide their learners with the best teaching quality, pedagogical knowledge and skills, teaching approaches and methods, and assessment and feedback giving. This also reminds school leaders and educators that professional development opportunities should be created more frequently to the teachers. Teachers should be sent to in-service training courses, seminars or conferences where they can update and learn new knowledge and skills in teaching English. For context-related factors, different stakeholders may play a role in creating the optimal input-output opportunities, teaching practices, learning activities, and learning environment for the students.

Further studies should be conducted to explore which factors have the strongest positive correlations with students' English proficiency gain. Different contexts and student subjects may yield different findings, which makes the whole picture of the topic even clearer provides more useful implications for related stakeholders.

\section{REFERENCES}


Aguilar, M., and Rodríguez, R., 2012. Lecturer and student perceptions on CLIL at a Spanish university. International Journal of Bilingual Education and Bilingualism. 15(2): 183-197.

Albino, G., 2007. Improving Speaking Fluency in a TaskBased Language Teaching Approach: The Case of EFL Learners at PUNIV-Cazenga. Sage Open. (7)2: 1-11.

Al-Mahrooqi1, R., 2012. A student perspective on low English proficiency in Oman. International Education Studies, 5 (6): 236-271. Available from http://www.ccsenet.org/journal/index.php/ies/article/view/19832.

Al-Mahrooqi, R., Denman, C., Al-Siyabi, J., and Al-Maamari, F., 2015. Characteristics of a good EFL teacher: Omani EFL teacher and student perspectives. SAGE Open. 5(2): 1-15. Available from http://journals.sagepub.com/doi/abs/10.1177/2158244015584782.

Andrews, S., 2001. The language awareness of the L2 teacher: Its impact upon pedagogical practice. Language Awareness. 10(2/3): 75-89.

Azarnoosh, M., and Tabatabaee, S. M., 2008. Teacher: A key to motivating language learners. Paper presented at the 6th International TELLSI Conference: Issues in Teaching English Language and Literature in Iran. Iran: University of Guilan.

Bahous, R., Bacha, N., and Nabhani, M. 2011. Motivating students in the EFL classroom: A case study of perspectives. English Language Teaching, 4(3): 33-43.

Baker, A. E., and Hengeveld, K., 2012. Linguistics. Oxford: Wiley-Blackwell, 450 pages.

Borg, S., 2006. The distinctive characteristics of foreign language teachers. Language Teaching Research. 10(1): 3-31.

Brosh, H., 1996. Perceived characteristics of the effective language teacher. Foreign Language Annals. 29 (2): 125-138.

Brown, D., 2007. Principles of language learning and teaching, Fifth Edition. White Plain, NY: Pearson Longman, 410 pages.

Chamot, A. U., and O'Malley, J. M., 1994. The CALLA handbook: Implementing the cognitive academic language learning approach. Reading, MA: AddisonWesley Publishing Company, 340 pages.

Chastain, K., 1988. Developing second language learning skills: Theory and practice, Third Edition. Chicago: Harcourt Brace Javanovich Publishers, 438 pages.

Collentine, J. and Freed, B. F., 2004. Learning context and its effects on second language acquisition. Studies in Second Language Acquisition. 26: 153-171.

Cook, V., 2016. Second language learning and language teaching, Fifth Edition. New York and London: Routledge, 334 pages

Costa, F., and Coleman, J. A., 2013. A survey of English-medium instruction in Italian higher education. International Journal of Bilingual Education and Bilingualism. 16(1): 3-19.
Crawford, C., 2014. Socio-economic differences in university outcomes in the UK: Drop-out, degree completion and degree class (Economic and Social Research Council edition). Warwick: University of Warwick and Institute for Fiscal Studies.

Cullen, R., 2002. The use of lesson transcripts for developing teachers' classroom language. In: Trappes-Lomax, H., Ferguson, G. (Eds.). Language in Language Teacher Education. John Benjamins Publishing Company. Amsterdam, 219-38.

Cummins, J., and Swain, M., 2014. Bilingualism in education: Aspect of theory, research and practice. London: Routledge, 254 pages.

Dafei, D., 2007. An exploration of the relationship between learner autonomy and English proficiency. Asian EFL Journal: Professional Teaching Articles 2007, pp. 2-23.

Daskalovska, N., Gudeva, L. K. and Ivanovska, B., 2012. Learner motivation and interest. Social and Behavioral Sciences, 46: 1187-1191.

Dörnyei, Z., 2007. Creating a motivating classroom environment. In: Cummins, J., Davison, C. (Eds.). International handbook of English language teaching. Springer. New York, pp. 719-731.

Elder, C., 2001. Assessing the language proficiency of teachers: Are there any border control? Language Testing. 18(2): 149-70.

Ellis, R. 2003. Second language acquisition (9th ed). Oxford: Oxford University Press, 151 pages.

Ellis, R., 2009. Task-based language teaching: Sorting out the misunderstandings. International Journal of Applied Linguistics. 19: 221-246.

Eun-Hee, L. and Hee Jeong, O., 2011. Relationship between motivation and proficiency improvement. Linguistic Research, 28(2): 405-430. Available at http://isli.khu.ac.kr/journal/content/data/28_2/9.pdf

Firth, A., and Wagner, J., 1997. On discourse, communication, and (some) fundamental concepts in SLA research. The Modern Language Journal, 81(3): 285-300.

Flowerdew, J., Levis, J., Zhang, Q. and Watkins, D., 2007. Conceptions of a good tertiary EFL teacher in China. TESOL Quarterly, 41(4): 781-790.

Freeman, D., 2016. Educating second sanguage teachers: The same things done differently. Oxford University Press. Oxford, 312 pages.

Gardner, R.C., 1985. Social psychology and second language learning: The role of attitudes and motivation. London: Edward Arnold, 208 pages.

Gardner, R., and Lambert, W., 1972. Attitudes and motivation in second language learning. Rowley, Massachusetts: Newsbury House, 313 pages.

Gass, S. M., and Mackey, A., 2007. Input, interaction, and output in second language acquisition. In: VanPatten, B., Williams, J. (Eds.). Theories in second language acquisition: An introduction. Lawrence Erlbaum. Mahwah, NJ, pp. 175-199. 
Geringer, J., 2003. Reflections on professional development: Toward high-quality teaching and learning. Phi Delta Kappan. 84(5): 373-377

Gharbavi, A., and Mousavi, S. A., 2012. Do language proficiency levels correspond to language learning strategy adoption?. English Language Teaching, 5 (7): 110-122. Available at http://dx.doi.org/10.5539/elt.v5n7p110

Green, A., 2014. Exploring Language Assessment and Testing - Language in Action. Routledge. New York, NY, 272 pages.

Hashemian, M. and Soureshjani, K. H., 2011. The interrelationship of autonomy, motivation, and academic performance of Persian L2 learners in distance education contexts. Theory and Practice in Language Studies, 1(4): 319-326.

Hedge, T., 2000. Teaching and Learning in the Language Classroom. Oxford: Oxford University Press. 448 pages.

Holmes, J., 2017. An introduction to sociolinguistics, Fifth Edition. New York: Routledge, 538 pages.

Housen, A., Schoonjans, E., Janssens, S., Welcomme, A., Schoonheere, E., and Pierrard, M., 2011. Conceptualizing and measuring the impact of contextual factors in instructed SLA - the role of language prominence. The Modern Language Journal, 49: 83-112.

İnal, S. , Evin, İ., and Saracaloğlu, A. S., 2003. The relation between students' attitudes toward foreign language and foreign language achievement. Dil Dergisi, 130: 38-53.

Jacobs, G. M., and Farrell, T. S., 2003. Understanding and Implementing the Clt (Communicative Language Teaching) Paradigm . RELC Journal. 34(1): 5-30.

Khattak, Z. I., Jamshed, T., Ahmad, A., and Baig, M. N., 2011. An investigation into the causes of English language learning anxiety in students at AWKUM. Procedia - Social and Behavioral Sciences, 15:1600-1604.

Krashen, S. D., 1985. The input hypothesis: Issues and implications. London: Longman. 120 pages.

Li, Z., 2009. A probe into classroom teaching and second language acquisition. International Education Studies. 2(1): 124-128.

Little, D., 2007. Language learner autonomy: Some fundamental considerations revisited. Innovation in language learning and teaching, 1(1): 14- 29.

Littlewood, W., 1984. Foreign and second language learning, language acquisition research and its implications for the classroom. New York: Cambridge University Press, 114 pages.

Liu, M., 2007. Chinese students' motivation to learn English at the tertiary level. Asian EFL Journal. 9 (1): 126-146. Available at https://www.asian-efljournal.com/1042/quarterly-journal/chinese-studentsmotivation-to-learn-english-at-the-tertiary-level/

Long, M. H., and Crookes, G., 1992. Three approaches to task-based syllabus design. TESOL Quarterly. 26(1), 27-56.
Mackey, A., 1999. Input, interaction, and second language development. Studies in Second Language Acquisition. 21: 557-587.

Mahmoud, A. M. and Thabet A., 2013. The qualities of the good English teacher as perceived by Saudi and Yemeni college students of English. Greener Journal of Educational Research. 3(2): 72-79.

Madhumathi, P., Ramani, N., and Prema, M., 2012. Language learning strategy use and English proficiency of below average Indian ESL students. Pertanika J. Soc. Sci. \& Hum, 22 (2): 455- 472. Available at http://www.pertanika.upm.edu.my/

Michigan Department of Education, 2011. Creating a supportive teaching and learning environment for English language learners. Available from http://www.michigan.gov/documents/mde/36_383780_7.pdf

Mitchell, D. E., Scott, L. D., Hendrick, I. G., and Boyns, D. E., 1998. The California Beginning Teacher Support and Assessment Program. 1998 Statewide Evaluation Study, 35 pages.

Mitchell, R., and Myles F., 2001. Second language learning: Key concepts and issues. In Christopher N. Candlin and Neil Mercer (eds.). English Language Teaching in its Social Context. London: Routledge. 11-27.

Mackey, A., 1999. Input, interaction, and second language development. Studies in Second Language Acquisition, 21:557-587.

Mahmoud, A. M., and Thabet, A., 2013. The qualities of the good English teacher as perceived by Saudi and Yemeni college students of English. Greener Journal of Educational Research, 3(2): 72-79.

Mohamadpour, P., 2013. Realization of autonomy and English language proficiency among Iranian high school students. Theory and Practice in Language Studies, 3 (7): 1187-1193.

Myartawan, I., and Latief, M. S., 2013. The correlation between learner autonomy and English proficiency of Indonesian EFL college learners. TEFLIN Journal, 24 (1): 63-81. https://www.researchgate.net/publication $/ 259762858$.

Nguyen, T.C. L., 2008. Learner autonomy and EFL proficiency: A Vietnamese perspective. Asian Journal of English Language Teaching, 18: 67-87.

Nel, N., and Müller, H., 2010. The impact of teachers' limited English proficiency on English second language learners in South African schools. South African Journal of Education, 30(4): 635-650.

Nikitina, L., 2011. Creating an authentic learning environment in the foreign language classroom. International Journal of Instruction, 4(1): 33-46.

Nisbet, D. L., Tindall, E. R., and Arroyo, A. A., 2005. Language learning strategies and English proficiency of Chinese university students. Foreign Language Annals, 38 (1): 100-106.

Normazidah, C. M., Koo, Y. L., and Hazita, A., 2012. Exploring English language learning and teaching in 
Malaysia. GEMA Online ${ }^{\mathrm{TM}}$ Journal of Language Studies, 12(1): 35-55.

Oxford, R. L., 1990. Language learning strategies: What every teacher should know. New York: Newbury House, 342 pages.

Park, G. P., 1995. Language learning strategies and beliefs about language learning of university students learning English in Korea. Unpublished Doctoral Dissertation. The University of Texas at Austin, Texas.

Pica, T., Lincoln-Porter, F., Paninos, D., and Linnell, J., 1996. Language learners' interaction: How does it address the input, output, and feedback needs of L2 learners? TESOL Quarterly. 30(1): 59-84.

Phon, S., 2017. Factors affecting the English language proficiency of students majoring in English at a rural university in Cambodia. UC Occasional Paper Series, 1(1): 69-92.

Punthumasen, P., 2007. International program for teacher education: An approach to tackling problems of English education in Thailand. In The 11th UNESCO-APEID International Conference Reinventing Higher Education: Toward Participatory and Sustainable Development (pp. 12-14).

Richards, H., Conway, C., Roskvist, A., and Harvey, S., 2013. Foreign language teachers' language proficiency and their language teaching practice. The Language Learning Journal, 41(2): 231-246.

Richards, J. C., 2006. Communicative language teaching today. Cambridge University Press. New York, 52 pages.

Ross, C. E., and Wu, C. L., 1995. The links between education and health. American Sociological Review, 60:719-45.

Rubin, J., 1975. What the "good language learner" can teach us. TESOL Quarterly, 9(11): 41-90.

Shoebottom, P., 2016. The factors that influence the acquisition of a second language. Available from http://esl.fis.edu/teachers/support/factors.htm

Shulman, L.S., 1987. Knowledge and teaching: foundations of the new reform. Harvard Educational Review. 57: $1-22$.

Souriyavongsa, T., 2013. Factors causes students low English language learning: A case study in the National University of Laos. International Journal of English Language Education, 1(1): 179-192.

Spolsky, B., 1989. Conditions for second language learning: Introduction to a general theory. Oxford: Oxford University Press, 272 pages.

Tanveer, M., 2007. Investigation of the factors that cause language anxiety for ESL/EFL learners in learning speaking skills and the influence it casts on communication in the target language (Unpublished master's thesis). University of Glasgow, Glasgow, UK.
Tarone, E., 2007. Sociolinguistic approaches to second language acquisition research-1997-2007. The Modern Language Journal, 91: 837-848

Thanasoulas, D., 2002. Motivation and motivating in the foreign language Classroom. The Internet TESOL Journal. 11(8): 2-7.

Ming, T. S., Ling, T. S., Jaafar, N. M., 2011. Attitudes and motivation of Malaysian secondary students towards learning English as a second language: A case study. The Southeast Asian Journal of English Language Studies 17(1): 40 - 54. Available from http://journalarticle.ukm.my/2047/1/5._3LVol17(1)2011Thang_Siew _Ming_et_al_doc.pdf.

Trawiński, M., 2005. An Outline of Second Language Acquisition Theories. Krakow: Academic Pedagogic, 92 pages.

Uys, M., Walt, J. V. D., Berg, R. V. D., and Botha, S., 2007. English medium of instruction: A situation analysis. South African Journal of Education. 27(1): 69-82.

Vann, R. J., and Abraham, R. G., 1990. Strategies of unsuccessful language learners. TESOL Quarterly, 24(2): 177-198.

VanPatten, B. and Willaims, J., 2007. Early theories in second language acquisition. In: B. VanPatten, and J.Williams (Eds.). Theories in second language acquisition: An introduction. Mahwah, NJ: Lawrence Erlbaum, pp. 17-35.

Wang, C., 2009. On linguistic environment for foreign language acquisition. Asian Culture and History, 1(1): 58-62.

Wang, Q., and Castro, C. D., 2010. Classroom interaction and language output. English Language Teaching, 3(2): 175-186.

Winke, P. M., 2005. Promoting motivation in the foreign language classroom.Available from http://clear.msu.edu/clear/newsletter/fall2005.pdf

Wong, R. M. H., 2010. The effectiveness of using English as the sole medium of instruction in English classes: Student responses and improved English proficiency. Porta Linguarum. 13: 119-130.

Wongsothorn, A., Hiranburana, K., and Chinnawongs, S., 2002. English language teaching in Thailand today. Asia pacific journal of education, 22(2): 107-116.

Young, J. W., Freeman, D., Hauck, M. C., Garcia Gomez, P., and Papageorgiou, S., 2014. A Design Framework for the ELTeach Program Assessments (ELT Research Report No. RR- 13-46). Educational Testing Service. Princeton, NJ, 29 pages.

Zhang, H., Alex, H. and Kortner, N. 1995. Oral language development across the curriculum, K12. ERIC Digest. ERIC Clearinghouse on Reading English and Communication, Bloomington, IN. ED389029. 